Article

\title{
Agricultural Technical Efficiency of Smallholder Farmers in Ethiopia: A Stochastic Frontier Approach
}

\author{
Markose Chekol Zewdie ${ }^{1,2, *(\mathbb{D}}$, Michele Moretti ${ }^{1,3} \mathbb{D}$, Daregot Berihun Tenessa ${ }^{2}$, Zemen Ayalew Ayele ${ }^{4}$,
} Jan Nyssen ${ }^{5}\left(\mathbb{D}\right.$, Enyew Adgo Tsegaye ${ }^{6}$, Amare Sewnet Minale ${ }^{7}$ and Steven Van Passel ${ }^{1,2}{ }^{(1)}$

1 Department of Engineering Management, Faculty of Business and Economics, University of Antwerp, Stadscampus, Prinsstraat 13, 2000 Antwerp, Belgium; michele.moretti@uantwerpen.be (M.M.); steven.vanpassel@uantwerpen.be (S.V.P.)

2 Department of Economics, Peda Campus, College of Business and Economics, Bahir Dar University, Bahir Dar P.O. Box 79, Ethiopia; daregot.berihun@bdu.edu.et

3 Department of Agriculture, Food and Environment, University of Pisa, via del Borghetto 80, 56124 Pisa, Italy

4 Department of Agricultural Economics, Zenzelima Campus, Bahir Dar University, Bahir Dar P.O. Box 79, Ethiopia; Zemen.Ayalew@bdu.edu.et

5 Department of Geography, Ghent University, Krijgslaan 281, S8, 9000 Gent, Belgium; Jan.Nyssen@ugent.be

6 Department of Natural Resource Management, Zenzelima Campus, Bahir Dar University, Bahir Dar P.O. Box 79, Ethiopia; enyewa@bdu.edu.et

7 Department of Geography and Environmental Studies, Peda Campus, Bahir Dar University, Bahir Dar P.O. Box 79, Ethiopia; amare.sewunet@bdu.edu.et

* Correspondence: markose.chekolzewdie@uantwerpen.be or markmarkcheck@gmail.com; Tel.: +251-(0)912338944

check for updates

Citation: Zewdie, M.C.; Moretti, M.; Tenessa, D.B.; Ayele, Z.A.; Nyssen, J.; Tsegaye, E.A.; Minale, A.S.; Van Passel, S. Agricultural Technical Efficiency of Smallholder Farmers in Ethiopia: A Stochastic Frontier Approach. Land 2021, 10, 246. https://doi.org/10.3390/ land10030246

Academic Editor: Elisa Marraccini

Received: 6 February 2021

Accepted: 22 February 2021

Published: 1 March 2021

Publisher's Note: MDPI stays neutral with regard to jurisdictional claims in published maps and institutional affiliations.

Copyright: (c) 2021 by the authors Licensee MDPI, Basel, Switzerland. This article is an open access article distributed under the terms and conditions of the Creative Commons Attribution (CC BY) license (https:/ / creativecommons.org/licenses/by/ $4.0 /)$.
Abstract: In the past decade, to improve crop production and productivity, Ethiopia has embarked on an ambitious irrigation farming expansion program and has introduced new large- and small-scale irrigation initiatives. However, in Ethiopia, poverty remains a challenge, and crop productivity per unit area of land is very low. Literature on the technical efficiency (TE) of large-scale and small-scale irrigation user farmers as compared to the non-user farmers in Ethiopia is also limited. Investigating smallholder farmers' TE level and its principal determinants is very important to increase crop production and productivity and to improve smallholder farmers' livelihood and food security. Using 1026 household-level cross-section data, this study adopts a technology flexible stochastic frontier approach to examine agricultural TE of large-scale irrigation users, small-scale irrigation users and non-user farmers in Ethiopia. The results indicate that, due to poor extension services and old-style agronomic practices, the mean TE of farmers is very low (44.33\%), implying that there is a wider room for increasing crop production in the study areas through increasing the TE of smallholder farmers without additional investment in novel agricultural technologies. Results also show that large-scale irrigation user farmers (21.05\%) are less technically efficient than small-scale irrigation user farmers $(60.29 \%)$. However, improving irrigation infrastructure shifts the frontier up and has a positive impact on smallholder farmers' output.

Keywords: a technology-flexible stochastic frontier approach; Ethiopia; irrigation user and non-user farmers; large-scale irrigation user farmers; small-scale irrigation user farmers

\section{Introduction}

Irrigation farming has come a long way since it was first conceived 8000 years ago. For thousands of years, irrigation farming was used by ancient civilizations to provide water to the farm plots, and this farming technique remains an important agricultural practice across the globe. Worldwide, irrigated agriculture accounts for approximately about four-fifths of global water withdrawals and one-fourth of cropland but contributes to $40 \%$ of food production. The share of irrigated land ranges widely, from $4 \%$ of the total area cropped in Africa to $42 \%$ in South Asia. In 2012, China and India were the 
two leading countries, accounting for $21.3 \%$ and $20.6 \%$ of worldwide irrigated land area, respectively [1]. Although there is high potential, irrigation farming in Africa is not as developed as in Asia. In Africa South of the Sahara (ASS) in general and in Ethiopia in particular, food production is almost entirely rainfed. In 2011, $0.4 \%$ of agricultural land in Ethiopia was irrigated. Over the past ten years, the share of irrigated land in the country ranged from $0.5 \%$ in 2007 to $0.3 \%$ in 2001 [2]. However, Ethiopia has abundant water resources and has some of the largest fresh surface water resources of all countries in Africa south of the Sahara. This large water resource potential for irrigation development is important for improving the performance of the agricultural sector. Ethiopia also has a million hectares of potentially irrigable land that can be used to improve agricultural production and productivity [3]. Ethiopia has an irrigation potential of 5.3 million ha of land, of which 3.7 ha can be developed for irrigation farming using surface water sources [4]. However, despite this water resource potential for irrigation development, agriculture in Ethiopia is traditionally subsistence-based and rainfed [5]. The rainfall pattern in Ethiopia is highly variable and is also unreliable, which has negatively affected the agriculture sector and Ethiopia's economy. As a result, poverty remains a challenge, and over 22 million people are living below the national poverty line [6].

Although the agricultural sector is traditionally subsistence-based, agriculture is the main source of income in Ethiopia's economy. The sector contributes $34 \%$ of the gross domestic product (2017) and creates job opportunities for $66 \%$ of the workforce (2018) [7]. The high economic importance with great growth potential and low productivity makes the agricultural sector strategically important in Ethiopia's economy. Considering the abundant water resource potential for irrigation farming in the country, irrigation development has been identified and considered as a key in stimulating rural development in Ethiopia. In the past decade, aiming to improve crop production and productivity in the country, Ethiopia has embarked on an ambitious irrigation farming expansion program and has introduced new large-scale and small-scale irrigation initiatives. An illustrative example of such effort is the Koga large-scale irrigation project located in the Lake Tana catchment in northwest Ethiopia, which provides water for around 7000 hectares of smallholder farmers during the dry season. Also important is the Fogera small-scale irrigation scheme, where a significant number of farmers are practicing small-scale irrigation farming and growing different types of crops in the dry crop seasons. According to Awulachew [8], large-scale irrigation is an irrigation scheme covering more than 3000 hectares, mainly relying on surface water in dams that is typically commercially or publicly sponsored. Small-scale irrigation, on the other hand, is an irrigation scheme that is often community-based using traditional methods, and covering less than 200 hectares.

Even though irrigation development is expanding in Ethiopia, crop productivity per unit area of land remains very low due to various constraints including the limited use of appropriate productivity-boosting technologies and appropriate crop management practices [9]. However, as resources are limited in Ethiopia, it would not be cost-effective to introduce new technologies without efficiently using the existing inputs and technologies [10]. Therefore, investigating how smallholder farmers are technically efficient in utilizing resources such as land, labor and capital and identifying its determinants are very important to increase crop production and productivity and to improve smallholder farmers' livelihood and food security. Given the aspiration of expanding irrigation development in Ethiopia, understanding how smallholder farmers with different farming system types (large-scale irrigation user farmers (LSIU), small-scale irrigation user farmers (SSIU) and non-user farmers (NU)) are currently performing is important in order to identify potential areas for interventions. However, little attempt has been made to understand the performance of large and small-scale irrigation user farmers as compared to the nonuser farmers in Ethiopia. Previous studies focused on the difference between irrigation user and non-user farmers in income [11-13], quality of life [11,12,14] and the impact of having access to irrigation on poverty $[15,16]$ and food security [17] without considering the differences in the technical efficiency (TE) of smallholder farmers. The results of these 
studies have shown that irrigation user farmers produce more, earn a better income, have a relatively better life, and are relatively rich and food-secure than the non-user smallholder farmers. However, as the resources are limited, higher income (output) or better quality of life without efficient use of resources cannot be a guarantee to bring sustainable development. Thus, which farm system type (LSIU, SSIU or NU farmers) is more efficiently utilizing the available resources, and what are the determinates of the TE of smallholder farmers have become an important empirical question.

However, studies on agricultural TE of smallholder farmers in Ethiopia that explicitly consider potential heterogeneity in technologies between farm system types and production environments are scarce. Considering potential heterogeneity in technologies between farm system types (LSIU, SSIU, NU) could potentially lead to unbiased estimates of economies of scale and scope [18]. In addition to the difference in farming system types, smallholder farmers in Ethiopia are very heterogeneous in size too. In the stochastic frontier framework, ignoring heteroscedasticity leads to inconsistent estimates [19]. In this study, as smallholder farmers in Ethiopia are heterogeneous both in size and farming system types, we assumed a non-constant error variance of the idiosyncratic error term, which may lead to sound estimates of agricultural TE. Our approach allows farming-system-typespecific technologies to be estimated jointly without separating the sample. It is therefore possible to test statistically whether the assumption of common technology is appropriate.

By specifying a more general distributional form of inefficiency effects (the truncated normal), in this study, we also attempted to address the criticism - there is a high probability that the inefficiency effects are about zero, which implies a relatively high TE-of the halfnormal and exponential distributional form for the technical inefficiency. Considering the research gap explained above, this study specifically addresses the following questions:

1. Are irrigation user smallholder farmers technically efficient?

2. Which smallholder farming system type is technically more efficient?

3. What are the determinants of the technical efficiency of smallholder farmers in Ethiopia?

The remainder of the paper is organized as follows. The next section explains the materials and methods, which includes the description of the study area, the data used, methods and model specification. The results and discussions are presented in Section 3, followed by a conclusion of the study in Section 4 .

\section{Materials and Methods}

\subsection{Description of the Study Area and the Data Used}

The study was conducted in Mecha and Fogera districts of northwest Ethiopia (Figure 1). Merawi is the capital of the Mecha district and is about $30 \mathrm{~km}$ from Bahir Dar, the Amhara regional state capital, whereas Woreta is the capital of Fogera district and is $55 \mathrm{~km}$ from Bahir Dar. Merawi and Woreta are located $575 \mathrm{~km}$ and $625 \mathrm{~km}$ northwest of the national capital Addis Ababa, respectively. The two main rivers in the Fogera district are Rib and Gummara, both of which drain into Lake Tana. The Fogera district is rich in both surface- and groundwater that can be used for irrigation farming during dry crop seasons. A significant number of farmers are practicing small-scale irrigation farming and growing different types of crops in the dry crop seasons. However, the irrigation facilities are not as well developed as in the Mecha district, where Koga large-scale irrigation farming is operational. In the Fogera small-scale irrigation scheme, the majority of the canals are earthen, most of the cemented canals are broken and are not well constructed, and some of the farm plots are far from the sources of irrigation water [12,20]. In the Mecha district, on the other hand, irrigation water-based on gravity-flows from the reservoir to the farm plots via long and well-constructed cemented canals, which provide water for around 7000 hectares of land during the dry season [11]. 


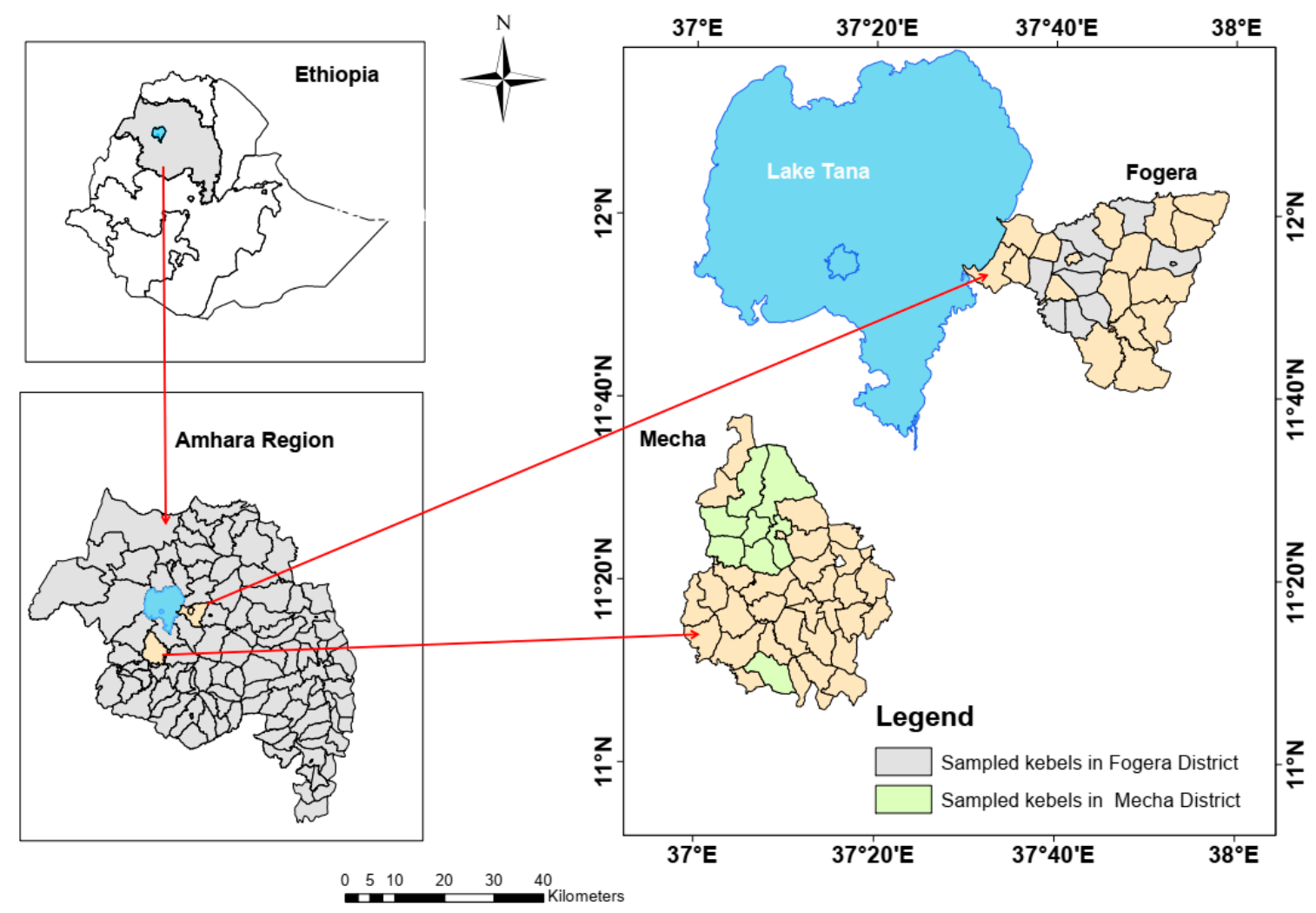

Figure 1. Study area (Source: Authors own elaboration).

This study is based on a unique cross-sectional dataset collected through a structured household survey prepared with Qualtrics (a web-based software that allows the user to create surveys and generate reports). The total number of sampled households of this study is 1026 of these 450 from the Mecha district (254 are large-scale irrigation user farmers and 196 are irrigation non-user farmers) located in the 12 Kebeles (the smallest administrative unit in Ethiopia) where the Koga large-scale irrigation water can be brought by gravity to the farm plots. The remaining 576 (308 are small-scale irrigation user farmers and 268 are irrigation non-user farmers) are from eight different Kebeles of the Fogera district of Ethiopia. The sampling procedure of this study was performed using a multi-stage sampling technique [21]. First, we have purposively selected the Mecha and Fogera districts of the Amhara region in Ethiopia as the Koga large-scale irrigation project is in the Mecha district and the Fogera small-scale irrigation scheme is in the Fogera district. In addition, these irrigation schemes were an illustrative example of the ambitious irrigation farming expansion program that the government of Ethiopia has embarked upon. Second, we purposively selected 12 small admirative unites (Kebeles) from the Mecha district as the Koga large-scale irrigation water, with gravity, flows from the Koga reservoir to the farm plots of these 12 Kebeles via a long and well-constructed cemented canal. In the Fogera district, on the other hand, we randomly selected eight small administrative units where smallscale irrigation farming was practiced. Third, based on each Kebeles' total population size, we defined the sample size to be collected for the two districts ( 450 households from Mecha and 576 households from Fogera district) considering the complexity of the population, the aims of the study and the kinds of the statistical manipulation used in the data analysis [21]. Finally, households from each Kebeles were randomly selected and interviewed (a face-to-face interview) with a structured household-level survey questionnaire that had been developed with Qualtrics. The survey covered family characteristics, plot-level characteristics, agricultural practices, yield, income, farming assets belonging to the household, available infrastructure, social relations and interactions with institutions. The first author of this manuscript, with the help of well-trained data collectors, conducted the household 
survey. Before the face-to-face interview, the field leader, who was a well-known and trusted member of the community, provided a preliminary introduction about the purpose of the study. Moreover, prior information from the field leaders about the respondents crop production, crop revenue and plot size helped the researchers identify whether the information provided by the respondents was inflated or underestimated. The 450 sampled household data of the Mecha district were collected in 2017 and the 576 sampled household data of Fogera district in 2018. In this study, we considered labor, land, and capital as inputs in the stochastic frontier analysis (SFA) model and the annual gross value of crops produced by smallholder farmers as output. In order to consider inflation effects on the total revenue, the dependent variable in our stochastic production function is the total crop revenue and the Fogera district households data collected one year after the data of Mecha district had been collected, we adjusted inflation for the prices of crops produced by smallholder farmers in the Fogera district. Variables potentially affecting the TE of smallholder farmers (e.g., education level of the household head, percentage of cash crop producer households, modern storage facilities, and modern dry facilities) have also been considered in the model (Table 1).

Table 1. Description of the variables used in the SFA model.

\begin{tabular}{|c|c|}
\hline Variables Name & Variable Description \\
\hline Annual value of crops (Q) & The gross value of total crops ${ }^{1}$ produced by the smallholder farmers in a given crop production year $\left(\mathrm{ETB}^{2}\right)$ \\
\hline \multicolumn{2}{|r|}{ The } \\
\hline Labor (A) & Family members actively ${ }^{3}$ participating in the crop production (number) \\
\hline Land (B) & Area of land used to produce crops (in hectares) \\
\hline Capital (C) & Household farming assets ${ }^{4}$ used by smallholder farmers (number) \\
\hline \multicolumn{2}{|l|}{ Farmers characteristics } \\
\hline Family size & Total number of family members of the household (number) \\
\hline Education & Household head education level (years of education) \\
\hline Gender & 1 if the household head is male, 0 otherwise. \\
\hline Plot level characteristics & The ratio of inactive ${ }^{5}$ to active family members of the household. \\
\hline Plot soil quality & $\begin{array}{r}\text { Soil fertility of the farm plot (Likert scale: very satisfactory }=5 \text {; satisfactory }=4 \text {; moderate }=3 \text {; unsatisfactory } \\
=2 \text {; very unsatisfactory }=1)\end{array}$ \\
\hline \multicolumn{2}{|r|}{ - 2, very ursatsiactory - 1) - } \\
\hline Improved storage facilities ${ }^{6}$ & 1 if farmer has improved storage facilities, 0 otherwise. \\
\hline Crop dry facilities ${ }^{7}$ & 1 if farmer has crop dry facilities, 0 otherwise. \\
\hline \multicolumn{2}{|l|}{ Access to technologies } \\
\hline Irrigation options & Farm system types (large-scale irrigation user $=2 ;$ small-scale irrigation user $=1 ;$ non-users $=0$ ) \\
\hline Irrigation water availability & $\begin{array}{l}\text { For how many times, in a year, farmers produce crops using irrigation water. (2: if yes for } 2 \text { times; } 1 \text { : if yes for } \\
1 \text { time; and } 0 \text {, if no) }\end{array}$ \\
\hline Extension & Frequency of household head contact with extension agents (number) \\
\hline $\mathrm{L}$ & 1 if a household is LSIU, 0 otherwise. \\
\hline S & 1 if a household is SSIU, 0 otherwise. \\
\hline \multicolumn{2}{|l|}{ Location } \\
\hline District (D) & 1 if a household is in Fogera district, 0 otherwise. \\
\hline \multicolumn{2}{|l|}{ Agronomic practices } \\
\hline Crop type & 1 if farmer produces cash crops, 0 otherwise. \\
\hline Crop rotation ${ }^{8}$ & 1 if farmer practices crop rotation, 0 otherwise. \\
\hline Mixed cropping 9 & 1 if farmer practices mixed cropping, 0 otherwise. \\
\hline Row planting 10 & 1 if farmer practices raw planting, 0 otherwise. \\
\hline
\end{tabular}

${ }^{1}$ The output of smallholder farmers often consists of more than one crop. Different crops therefore need to be aggregated to make comparison possible [22]; ${ }^{2}$ ETB = Ethiopian birr: at the time of the survey, 1 United States dollar (USD) $=26.9564$ ETB; ${ }^{3}$ Although households sometimes use hired labor and the help of other villagers, this represents a very small contribution. Thus, family labor sufficiently explains productivity differences among households; ${ }^{4}$ Ethiopian smallholder farmers have a very low capital intensiveness and very low access to machinery. Thus, in this study, capital is proxied by household farming assets, which are variety of tools that households use in the production process: animals used for cultivation and transportation of agricultural products; animal-drawn plough; broad bed and furrow maker (bbm); hand pump to lift water; treadle pump to lift water; knapsack sprayer; animal cart; water pump (powered); sheller; motorized thresher/combiner; grain winnower and others. (If the household owned only one of these farming assets = 1 , if they owned only two $=2$, if they owned only three $=3 \ldots$ ); ${ }^{5}$ Inactive family members: family members of the household who were not actively participated in the crop harvesting process; ${ }^{6}$ It is relatively advanced crop storage facilities that can keep them from being overrun by rodents; ${ }^{7}$ Any facilities that help farmers to dry their crops with sunlight; ${ }^{8}$ Crop rotation is the practice of growing different crops on the same land for successive seasons. It is a practice designed to preserve the productive capacity of the soil, and to build better soil structure and increase the ability to store carbon on the farm plots; ${ }^{9}$ This is a system of cropping in which farmers grow two or more crops simultaneously on the same piece of land at the same time. It can improve the fertility of the soil and increases crop yield by reducing the risks associated with a single crop failure; creates biodiversity, which attracts a variety of beneficial and predatory insects to minimize pests; and can also increase soil organic matter, fumigate the soil, and suppress weed growth; ${ }^{10}$ This involves growing seeds in straight line. This planting technique reduces input costs and increases yield. 
The mean and standard deviation (SD) of the output and inputs used in the SFA model are reported in Appendix A, Table A1. The mean annual gross value of crops produced by LSIU smallholder farmers (43,357.55 ETB: ETB = Ethiopian birr: at the time of the survey, 1 United States dollar $(\mathrm{USD})=26.9564$ ETB.) exceeds that of the SSIU farmers $(26,066.59$ ETB). Similar to the results of Zewdie et al. [11], the mean annual gross value of crops produced by irrigation user smallholder farmers in the study area $(33,881.37 \mathrm{ETB})$ is also higher than that of the non-user smallholder farmers (7429.93 ETB). In terms of input application, irrigation user smallholder farmers used relatively more inputs than the non-user farmers. The average labor and land inputs used in the production process also varies across irrigation farm system types. LSIU smallholder farmers used on average 3.87 labor and 0.445 hectares of land, whereas SSIU farmers used 2.46 labor and 0.288 hectares of land. However, regarding with the capital input (proxied by the household farming assets), SSIU farmers used on average 10.59 farming assets, which is relatively higher than the average farming assets (9.30) used by LSIU smallholder farmers. Concerning the determinants of the TE, LSIU smallholder farmers scored relatively higher mean values for the majority of the TE determinants than the SSIU farmers. Nevertheless, the average education level of the household head, modern crop storage and crop dry facilities, soil fertility of the farm plot, ratio of inactive to active members of the household, percentage of cash crop producer households and percentage of households with crop rotation practices is higher for the SSIU farmers. These mean differences remain significant between irrigation user farmers in general and the non-user farmers. Irrigation user farmers have a relatively higher mean for all the determinants of the TE of smallholder farmers in the study area (Appendix A, Table A1).

\subsection{Methods and Model Specification}

There are two important approaches to estimating smallholder farmers' TE level and its principal determinates: the parametric stochastic frontier analysis (SFA) approach and the non-parametric data envelopment analysis (DEA) approach. In technical (in)efficiency analysis, DEA has the power of accommodating multiple outputs and inputs and is less prone to specification error. However, it lumps the error term and inefficiency component together and fails to take into consideration the possible impact of random shocks (for example, measurement error) and other types of noise in the data [23]. The SFA, on the other hand, fails to accommodate multiple outputs and inputs and is easily influenced by mis-specification issues. However, SFA is widely applied in the TE study because of its ability to consider measurement error in the output and stochastic elements of production, thereby distinguishing the effect of noise from the effect of efficiency. Since agricultural output (revenue) in Ethiopia strongly depends on weather conditions and other exogenous random forces, agricultural output deviations from the frontier might not be entirely under the control of smallholder farmers. Therefore, we assumed agricultural output (revenue) to be a stochastic variable and selected SFA as the more appropriate analytical approach. In this study, we used SFA to estimate and explain the TE of LSIU and SSIU smallholder farmers as compared to the NU farmers and examine the determinants of the TE of smallholder farmers in northwest Ethiopia. The common criticism of the stochastic frontier approach (SFA) is that there is no a priori justification for the selection of any distributional form for the TE effects. The half-normal and exponential distributions of $U i$ are arbitrary selections. This implies that, as both distributional forms have a mode at zero, the probability of the inefficiency effect being about zero is high. This results in relatively high TE. However, in practice-especially in the Ethiopian case where the majority of smallholder farmers are illiterate with poor infrastructure-there are few very efficient farmers but many inefficient farmers such that the appropriate distribution of $U i$ should have a non-zero mode.

Although the question of which distributional assumption of $U i$ is the most likely scenario is an empirical one, the inflexibility of the half-normal distribution of $U i$ limits the exploration of the alternatives. Furthermore, as agriculture is the only source of 
employment for most of the smallholder farmers in Ethiopia, smallholder farmers are not operating in a competitive market and the inefficient farmers will not be forced out of the market in the long run, even when losses occur. In addition, the half-normal distribution has a single parameter and is inherently restrictive [24]. Thus, assuming and characterizing the distribution of $U i$ as a truncated normal (the inefficiency distribution has a nonzero mode) instead of a half-normal (most of the observations clustered nearly efficient) is appropriate for this study. If distributional assumptions of $U i$ are incorrect, the maximum likelihood estimation of the model parameters is likely to be inconsistent and the inefficiency index is likely to be biased [24]. In this study, we characterize $U i$ as a truncated normal distribution. By specifying a more general distributional form of inefficiency effects (the truncated normal), in this study, we attempted to address the criticism - there is a high probability that the inefficiency effects are about zero, which implies the relatively high TE-of the half-normal and exponential distributional form for the technical inefficiency effect.

\subsubsection{Stochastic Frontier Model Specification}

To estimate technical (in)efficiency across a cross-section of smallholder irrigation user (LSIU and SSIU) and non-user farmers, the stochastic frontier production function model (SFPF) proposed by Aigner et al. [25] was used. The SFPF is given as:

$$
\mathrm{Qi}=\mathrm{f}(x i ; \beta)+\xi
$$

where Qi is the total value of agricultural products (crops) of smallholder farmer $i$ produced in a given cropping year (2017/2018); $x i$ is a vector of inputs (labor (A), land (B), and capital (C)) used by smallholder farmer $i ; \beta$ is a vector of technology parameters to be estimated; and $\xi$ is an error term made up of two components:

$$
\xi=V i-U i .
$$

where $V i$ is a two-sided random error term that is assumed to be a symmetric disturbance and is independently distributed $\mathrm{N}\left(0, \sigma_{v}^{2}, i\right) ; i$ is a non-negative error term (truncated above zero) that captures the TE of smallholder farmer $i$ and is assumed to be independent of $\mathrm{Vi}$.

Following the works of Triebs et al. [18], the SFPF model, which was found to be an adequate representation of the data using likelihood ratio (LR) tests, is given by:

$$
\operatorname{lnQi}=\beta_{0}+\sum_{j=1}^{3} \beta_{j} \ln X_{j i}+\frac{1}{2}\left(\sum_{j=1}^{3} \sum_{k=1}^{3} \beta_{j k} \ln x_{j i} \ln x_{k i}\right)+\sum_{j=1}^{3} \beta_{j S} S \ln X_{j i}+\sum_{j=1}^{3} \beta_{j L} L \ln X_{j i}+\beta_{L} \mathrm{~L}+\beta_{S} S+\beta_{D} \mathrm{D}+(V i-U i)
$$

where the superscript $i$ stands for the $i$-th smallholder farmers in the sample $(i=1,2,3,4 \ldots$ 1026) and $j$ stands for the $j$-th inputs used in the production process (labor (A), land (B), and capital (C); In stands for natural logarithm); $L$ and $S$ are dummies for large-scale irrigation user and smallscale irrigation user smallholder farmers, respectively; $D$ is a vector of district dummies allowing for neutral output shift among different districts (Mecha and Fogera) (see [26,27]). The term $U i$ is a onesided $(U i \geq 0)$ efficiency component that captures the technical (in)efficiency of smallholder farmers. This component can follow different distributions: truncated-normal, half-normal, exponential or gamma $[24,28]$. Since agriculture is the only source of employment for most of the smallholder farmers in the study areas, smallholder farmers are not operating in a competitive market and inefficient farmers will not be forced out of the market in the long run. Thus, we assumed and characterized the distribution of $U i$ as a truncated normal distribution (the inefficiency distribution has a nonzero mode) instead of a half-normal distribution (most of the observations clustered were nearly efficient) [24]. Equation (3) represents a flexible production technology that allows the firstorder term production parameters to vary across the three farm system types (LSIU, SSIU and $\mathrm{NU}$ smallholder farmers). As the different smallholder farmers may employ different technologies and the SFPF model parameters may vary across smallholder farmer types, we also introduce input-smallholder farmer types interaction terms into the model. 
Since this study is based on a dataset that was collected from three different smallholder farmer types of the two different districts (the Fogera and Mecha districts), the technological and market conditions may vary across the three types of smallholder farmers. Thus, following the works of Triebs et al. [18], we include smallholder farmer types dummies in the SFPF model to control for unobserved heterogeneity. Moreover, as the size of the farmers varies across the three types of smallholder farmers, the three categories may have different error variance and thus the problem of heteroskedasticity could arise [29-31]. Unlike the classical models in which heteroskedasticity affects only the efficiency of the estimators and not their consistency, Kumbhakar and Lovell [32] and Wang and Schmidt [19] provide a detailed discussion on the consequence of ignoring heteroskedasticity. Ignoring heteroskedasticity of $V i$ still gives consistent estimates of the frontier function parameters ( $\beta$ ) except for the intercept, which is downward-biased, and estimates of the TE are biased. Ignoring the heteroskedasticity of $U i$ causes biased estimates of the frontier function's parameters as well as the estimates of TE. Thus, we employ a model that allows for heteroskedasticity in $\mathrm{Vi}$ (as a function of the family size of smallholder farmers (lnsize)) and $U i$ (as function of vector of observable variables, which can also be used as TE determinants).

Finally, we estimated the TE according to Jondrow [33]:

$$
\mathrm{TE} i=\frac{Q i *}{Q i}=\exp \{-U i\}
$$

where $Q i^{*}$ and $Q i$ are the stochastic frontier and the observed output for the $i$ th smallholder farmer, respectively.

In a truncated normal distributional assumption of $U i$, there are several ways to make the farmers' technical (in)efficiency a function of exogenous variables, which can be used as TE determinants. The Battese model [34] abandoned the constant mean assumption on $\mu$ (mean of truncated normal distribution) and instead parametrizes $\mu$ by a function of exogenous variables. This makes the distributional shape of $U i$ more flexible because, in contrast to the Stevenson model [28], where the mean of the pre-truncated distribution is identical for all the observations, each observation now has an observation-specific mean of the pre-truncated distribution, with the mean determined by observation-specific variables. Caudill and Ford [35], Caudill [36] and Hadri [37] make $\sigma_{u, i}^{2}$ (variance of the technical (in)efficiency component) instead of $\mu$ a function of exogenous variables. However, Wang [38] suggests that neither approach can be easily justified, and the better parameterization approach may come from combining both features of the models such that the $\mu(\mathrm{mu})$ and $\sigma_{u, i}^{2}$ should be parametrized by the same vector of exogenous variables. In this study, we use this double parametrization, which is more flexible and accommodates the non-monotonic relationship between the TE and its determinates [38]. We, therefore, parametrize all the distribution parameters (i.e., $\mu$ and $\sigma_{u, i}^{2}$ ) in terms of underlying exogenous variables [39].

$$
\begin{gathered}
\mu=\delta_{0}+\sum_{m=1}^{9} Z_{m i} \delta_{m} \\
\sigma_{u, i}^{2}=\exp \left(\theta_{0}+\sum_{m=1}^{9} Z_{m i} \theta_{m}\right)
\end{gathered}
$$

where $\mu$ is mean of the distribution of the pre-truncated technical (in)efficiency component (Ui); $\sigma_{u, i}^{2}$ is the variance of the technical (in)efficiency component; $Z \_m$ is a vector of nine exogenous variables (see Table 1 ) of observation $i ; \delta$ and $\theta$ are the corresponding coefficient vector of exogenous variables for $\mu$ and $\sigma_{u, i}^{2}$, respectively.

\subsubsection{Hypothesis Test}

The hypotheses below have been investigated to examine the adequacy of the specified model used, the presence of inefficiency and the relevance of exogenous variables to explain the (in)efficiency component. The existence of common technology across farm system types and the assumption of the truncated normal distribution of the (in)efficiency component (Ui) have also been tested. These hypotheses have been tested using the generalized likelihood-ratio statistic (LR):

$$
\mathrm{LR}=-2[\ln \{L(\mathrm{H} 0)\}-\ln \{L(\mathrm{H} 1)\}]
$$

where $L(\mathrm{H} 0)$ and $L(\mathrm{H} 1)$ are values of the likelihood function under the null (H0) and alternative (H1) hypotheses, respectively. LR has approximately a Chi-square (or mixed Chi-square) distribution 
if the given null hypothesis is true with a degree of freedom equal to the number of parameters assumed to be zero in (H0).

(1) H0: $\beta j i=0$ : coefficients of the second-order variable in the translog model are zero. The LR statistic has a value equal to 53.085 , and the critical value at the $1 \%$ significance level of the test is 16.704 (Table 2). It is evident that the LR test result (LR statistic value is greater than the critical value of $X^{2}$ at $1 \%$ significance level of the test) rejects the null hypothesis and suggests that the translog specification is statistically a valid representation of the data and adequately captures the crop production behavior of smallholder farmers in the study area. We, therefore, use the translog specification to estimate the SFPF model in Equation (3).

Table 2. Hypotheses test results.

\begin{tabular}{cccc}
\hline Hypothesis & $\begin{array}{c}\text { LR Statistics } \\
(\boldsymbol{\lambda})\end{array}$ & $\begin{array}{c}\text { LR Critical } \\
\left(\chi_{0.01}^{2} / \text { mixed } \chi_{0.01}^{2}\right)\end{array}$ & $\begin{array}{c}\text { Decision on the Null } \\
\text { HyPothesis }\end{array}$ \\
\hline 1. H0: $\beta j i=0$ & 53.085 & 16.704 & Rejected \\
2. H0: $\sigma_{u, i}^{2}=0 ; \mu=0$ & 205.312 & 50.284 & Rejected \\
3. H0: $\mu=0$ & 104.192 & 28.485 & Rejected \\
4. H0: $\sigma_{v, i}^{2}=0$ & 24.622 & 8.273 & Rejected \\
5. H0: $\beta \_L=\beta \_S=0 ;$ & & & Rejected \\
B_AL $=\beta \_$AS $=0 ;$ & 246.360 & 19.384 & \\
3_BL $=\beta \_B S=0 ;$ & & & \\
B_CL $=\beta \_C S=0$ & & & \\
\hline
\end{tabular}

(2) H0: $\sigma_{u, i}^{2}=0 ; \mu=0$ : the (in)efficiency effects are non-stochastic. The null hypothesis of no (in)efficiency component is also rejected, implying that the stochastic frontier approach (SFA) is more appropriate than the ordinary least square estimation (OLS) and that there is significant technical (in)efficiency variation among the smallholder farmers. The estimated value of $\gamma$ (0.197) indicates that the difference between the actual and the maximum possible (efficient) output of the sampled farmers in the study area is due to both random errors and the inefficient use of resources and reflects the presence of inefficiency in the data set.

(3) H0: $\mu=0$ : the distributional form of the (in)efficiency component (Ui) in the SFPF model is a half-normal distribution. The third hypothesis testing is about the distributional assumption of the one-sided error term. Given that the translog stochastic frontier production function best fits the data, we test whether the TE level is better estimated using a half-normal $(\mu=0)$ or a truncated-normal distributional assumption of $\mathrm{U} i(\mu>0)$. The LR statistic has a value equal to 104.192, and the critical value at the $1 \%$ significance level of the test is 28.485 . This LR test result clearly supports the truncated-normal frontier specification with determinants of (in)efficiency over the half-normal specification.

(4) H0: $\sigma_{v, i}^{2}=0$ : the idiosyncratic (random shock) component $(V)$ of the error term is homoscedastic and not a function of the family size of the household. However, the LR test result rejects the null hypothesis of homoscedasticity and suggested that family size is relevant for modeling heteroskedasticity in the random shock component $(V)$ of the error term.

(5) $\quad H 0: \beta \_L=\beta \_S=0 ; \beta \_A L=\beta \_A S=0 ; \beta \_B L=\beta \_B S=0 ; \beta \_C L=\beta \_C S=0$ : the three farming system types used by smallholder farmers have the same technology. The LR test result, however, rejects the null hypothesis of the same technology assumptions and suggests that the pooled model (without interaction terms) is not appropriate for the data. As a result, we use input farming system type interaction variables.

\section{Results and Discussion}

\subsection{Econometric Results of the SFPF Model Estimation}

The parameters of the truncated-normal stochastic production frontier and the (in)efficiency effects models were estimated using a single-step procedure and confirmed that the overall SFPF model of this study is statistically significant (Table 3). The results reveal that the estimated first-order coefficients of all the three inputs have the expected positive signs, and only two of them (Land $(\ln B)$ and Capital $(\ln C)$ ) have a statistically significant effect on crop production in the study area at 1 and 5\% significance levels, respectively. The statistically significant positive (negative) coefficients of cross-products, on the other hand, are complementarity (substitutability) between inputs. In this study, however, none of the cross-product estimated parameters are statistically significant. 
Although the two districts are in a similar agroecological zone, the two locations of this study area appeared to differ significantly with respect to the intercept of the production frontier. The estimated coefficient of the variables, LSIU and district, were positive and statistically different from zero at a $1 \%$ level of significance, implying that the Fogera district as compared to the Mecha district and the LSIU as compared to SSIU and non-user farmers were relatively better to produce more crops assuming that other things remain constant.

Table 3. Results of translog SFPF model estimates.

\begin{tabular}{|c|c|c|c|c|c|c|c|}
\hline \multirow{2}{*}{$\begin{array}{l}\text { Frontier } \\
\text { Constant }\end{array}$} & \multicolumn{3}{|c|}{ Coefficients and S.E } & \multirow{2}{*}{$\begin{array}{c}\begin{array}{c}\text { Inefficiency } \\
\text { Model }\end{array} \\
\text { Constant } \\
\end{array}$} & \multicolumn{3}{|c|}{ Coefficients and S.E } \\
\hline & 9.527 & & $(0.254)$ & & 0.316 & & $(0.287)$ \\
\hline $\ln \mathrm{A}$ & 0.393 & & $(0.280)$ & lnSize & 0.696 & $* * *$ & $(0.124)$ \\
\hline $\ln B$ & 1.123 & $* * *$ & $(0.186)$ & Education & -0.017 & $* *$ & $(0.007)$ \\
\hline $\ln C$ & 0.398 & $* *$ & $(0.200)$ & Gender & -0.094 & & $(0.101)$ \\
\hline$S \ln A \ln A$ & 0.222 & & $(0.211)$ & Extension & -0.008 & & $(0.025)$ \\
\hline$S \ln B \ln B$ & 0.269 & $* *$ & $(0.104)$ & $\begin{array}{l}\text { Plot soil } \\
\text { quality }\end{array}$ & -0.151 & $* * *$ & $(0.031)$ \\
\hline$S \ln C \ln C$ & -0.233 & & $(0.169)$ & $\begin{array}{l}\text { Improved } \\
\text { storage } \\
\text { facilities }\end{array}$ & -0.119 & * & $(0.065)$ \\
\hline $\ln A \ln B$ & 0.137 & & $(0.100)$ & $\begin{array}{l}\text { Crop dry } \\
\text { facilities }\end{array}$ & 0.128 & * & $(0.073)$ \\
\hline $\ln A \ln C$ & 0.071 & & $(0.126)$ & $\begin{array}{l}\text { Irrigation } \\
\text { options }\end{array}$ & 0.640 & $* * *$ & $(0.172)$ \\
\hline $\ln B \ln C$ & -0.040 & & $(0.091)$ & $\begin{array}{c}\text { Irrigation } \\
\text { water } \\
\text { availability }\end{array}$ & -0.440 & $* * *$ & $(0.092)$ \\
\hline SSIlnA & -0.070 & & $(0.217)$ & $\begin{array}{l}\text { Dependency } \\
\text { ratio }\end{array}$ & -0.116 & $* * *$ & $(0.030)$ \\
\hline SSIlnB & 0.103 & & $(0.154)$ & Crop type & -0.488 & $* * *$ & $(0.065)$ \\
\hline SSIlnC & 0.301 & & $(0.237)$ & Crop rotation & 0.301 & $* * *$ & $(0.068)$ \\
\hline LSIlnA & -0.063 & & $(0.200)$ & $\begin{array}{l}\text { Mixed } \\
\text { cropping }\end{array}$ & -0.041 & & $(0.076)$ \\
\hline LSIlnB & -0.169 & & $(0.155)$ & Row planting & -0.179 & $* *$ & $(0.057)$ \\
\hline $\begin{array}{l}\text { LSIlnC } \\
\text { ISIU }\end{array}$ & 0.064 & $* * *$ & $\begin{array}{l}(0.231) \\
(0.575)\end{array}$ & \multicolumn{4}{|c|}{ Heteroskedasticity Model Vsigma $\left(\sigma_{v, i}^{2}\right)$} \\
\hline SSIU & 0.511 & & $(0.448)$ & Constant & -1.920 & $* * *$ & $(0.191)$ \\
\hline District & 0.360 & $* * *$ & $(0.081)$ & $\begin{array}{c}\text { lnSize } \\
\text { Diagnostic } \\
\text { statistics }\end{array}$ & 0.348 & * & $(0.386)$ \\
\hline$\sigma_{v}$ & 0.531 & & & Wald chi2(18) & & & \\
\hline$\sigma_{u}$ & 0.263 & & & Prob > chi2 & & & \\
\hline$\sigma^{2}$ & 0.351 & & & $\begin{array}{l}\log \\
\text { likelihood }\end{array}$ & & & \\
\hline$\gamma$ & 0.197 & & & $\begin{array}{c}\text { Number of } \\
\text { obs (N) }\end{array}$ & & & \\
\hline
\end{tabular}

Note: Figures in parentheses are standard errors. ${ }^{* * *},{ }^{* *}$, and ${ }^{*}$ denote statistically significant at the 1,5 and $10 \%$ levels, respectively. $\mathrm{A}=$ Labor; $\mathrm{B}=$ Land; $\mathrm{C}=$ Capital and $\mathrm{ln}=$ natural logarithm.

The diagnostic statistics at the bottom of Table 3 indicated that the overall SFPF model of this study is statistically significant at a $1 \%$ significance level, and that the assumption of heteroskedasticity both in the idiosyncratic component $(V i)$ and the (in)efficiency component ( $U i)$ are supported by the data. In modeling the heteroskedasticity of $V i$, family size of the household is found to be relevant in explaining the variance of the random error component. The estimated parameter of the family size of the household in the heteroskedasticity model of $V i$ is positive and statistically significant at a $10 \%$ significance level. This means that, on average, the output of smallholder farmers with greater family size is found to be more volatile.

In a translog SFPF model, output elasticities may vary across data points and are therefore computed at the inputs' sample mean. The output elasticities associated with all three inputs 
were positive, and only two of them were lower than one (see Table 4). Due to the second-order terms, as the model is a translog SFPF, the estimated coefficients in Table 3 cannot be interpreted as output elasticities. Output elasticities calculated as derivatives do not make sense for dummy variables such as for LSIU and district as they are dichotomous and not expressed as a natural logarithm in the SFPF model. The marginal effect (ME) of dummy variables should therefore be interpreted as the percentage effect on the output of a change from zero to one in the dummy input variables [40]. The ME of LSIU, for instance, means that under the same use of other input variables, SSIU and NU smallholder farmers could increase their crop production by a factor of 5.77 if they have access to large-scale irrigation water. This implies that improving irrigation infrastructure can shift the frontier up and has a positive impact on smallholder farmers' output. The same result is obtained by $[11,41,42]$.

Table 4. Output elasticities of inputs at the sample mean and RTS scores.

\begin{tabular}{cccccccc}
\hline & \multicolumn{7}{c}{ Statistically Significant First-Order Input Variables } \\
\cline { 2 - 8 } $\begin{array}{c}\text { Output } \\
\text { Elasticities }\end{array}$ & Labor & Land & Capital & RTS & District & LSIU \\
\cline { 2 - 8 } & 0.967 & 1.658 & 0.431 & 3.056 & Marginal & 0.67 & 5.77 \\
& $(0.424)$ & $(0.367)$ & $(0.473)$ & $(0.521)$ & effect (ME) & & \\
\hline
\end{tabular}

Note: Output elasticities are computed at sample mean and the values in parenthesis are standard errors.

In line with the results of $[43,44]$, land size was found to be the most important factor of production with the highest level of elasticity (1.658). This indicates that farmers are operating in an irrational zone of production (increasing return to land). This is not surprising, given that smallholder farmers in the study areas were growing crops, on average, on a one-half hectare plot of land. The returns to scale (RTS) - the sum of the three inputs-is very high (3.056), implying that, on average, households operate under increasing RTS. In other words, a one percent increase in inputs would result in more than one percent increase in crop production in the study areas (see Table 4). Thus, the hypothesis that smallholder farmers in the study areas produce at a constant return to scale is rejected (see Appendix A, Table A2).

\subsection{Econometric Results of the Technical (in) Efficiency Model}

Parameter estimates of the determinants of the technical (in)efficiencies are presented in Table 3. In the estimated SFPF model, eleven out of fourteen technical (in)efficiency determinants were found to be statistically significant. Technical (in)efficiency determinants (gender, extension, and mixed cropping) with negative signs are not statistically significant. Assuming that the main role of extension agents is to help farmers to have the best farming practices and improve their efficiencies, the statistical insignificance of the extension variable is surprising. However, as is explained by Zewdie et al. [12], agricultural extension workers in the study area are involved in activities that are not related to their normal duties. While Turner [45] found mixed cropping practice resulting in statistically significant positive effects on the TE of Australian smallholder farmers, in our study, mixed cropping practice is not statically significant. This result might also be related with poor extension services and limited knowledge of the farmers on how to properly practice mixed cropping farming techniques.

The parameters estimated in Table 3 of the (in)efficiency component only give basic information on the direction of the impact of the determinants of the (in)efficiency component. These variables have a direct effect not on the estimates of the (in)efficiency $(U i)$ but on the $\mu i$ of the truncated normal distribution of (in)efficiencies [24]. In Table 5, however, the mean TE scores and the average marginal effects of (in)efficiency determinants are presented. The average TE score in the study areas is $44.33 \%$ with variation ( $\mathrm{SD}=0.211$ ), indicating that there is wider room for increasing crop production in the study areas through mitigating the technical (in)efficiency of smallholder farmers without additional investment in novel agricultural technologies. This finding is lower than the TE scores estimated by empirical researchers in African countries $(59 \%, 66.18 \%, 74 \%$ and $78 \%$ for Ethiopia by Tenaye [43], Geffersa [46], Seyoum [47] and Abate [48], respectively; 78\% in Papua New Guinea by Coelli and Fleming [21]; and 82\% for Rwanda by Ngango and Kim [49]). Bogale and Bogale [50] also found that TE scores range from 77 to $97 \%$ for modern and traditional irrigation scheme user farmers in Ethiopia. Adams [51], on the other hand, found a TE score for Ghanaian farmers that ranges from 50.6 to $78.1 \%$ under the constant returns to scale (CRS) and the variable returns to scale (VRS) approach to estimate efficiency scores, respectively. Similarly, Tenaye [43] 
found a TE score for Ethiopia that ranges from 59\% to 30\% under the true fixed effects model (TFE) and the traditional model specification respectevely. The reason for the lower TE score in our study might be because, in this study, we have considered technology differences across the farm system types and properly specified the distributional assumption of the technical (in)efficiency component, Ui. A common technology assumption for different farm system types' technology could potentially lead to biased estimates of economies of scale and scope [18]. Similarly, a wrong assumption of $U i$ leads to inconsistent parameter estimates and a biased (in)efficiency index, which would result in high TE scores [24].

Table 5. Yield gap due to technical (in)efficiency.

\begin{tabular}{cccccc}
\hline \multirow{2}{*}{ Output } & \multicolumn{4}{c}{ Smallholder Farmers with Farm System Types } \\
\cline { 2 - 6 } & $\begin{array}{c}\text { Large-Scale } \\
\text { Irrigation User }\end{array}$ & $\begin{array}{c}\text { Small-Scale } \\
\text { Irrigation User }\end{array}$ & $\begin{array}{c}\text { All Irrigation } \\
\text { User Farmers }\end{array}$ & $\begin{array}{c}\text { All Non-User } \\
\text { Farmers }\end{array}$ & Overall Farmers \\
\hline Mean of value of & 43,358 & 26,067 & 33,881 & 7430 & 21,919 \\
observed output & $(70,435)$ & $(20,352)$ & $(50,381)$ & $(7208)$ & $(39,827)$ \\
Mean of value of & 187,138 & 45,327 & 109,420 & 16,045 & 67,192 \\
potential output & $(173,904)$ & $(38,267)$ & $(139,392)$ & $(14,959)$ & $(113,568)$ \\
Average yield & $-143,781$ & $-19,260$ & $-75,538$ & -8616 & $-45,273$ \\
gap/output loss & $(124,026)$ & $(23,255)$ & $(105,264)$ & $(9263)$ & $(84,935)$ \\
\hline
\end{tabular}

Note: Values in parenthesis are standard deviations.

The average TE scores vary across smallholder farmers with different farming system types in the study area (Table 6). SSIU farmers achieved the highest $(60.30 \%)$, whereas LSIU farmers were the most inefficient farm system type with a $21.05 \%$ average TE score. Regarding the mean TE scores between irrigation users and non-user farmers, the users scored a smaller TE level (42.56\%) than the non-users (46.48\%). Although improving irrigation infrastructure shifts the frontier up and has a positive impact on smallholder farmers' output, LSIU smallholder farmers were less TE than the SSIU and NU farmers. The prices of irrigation water being too cheap [52] and the inexperience of LSIU smallholder farmers in the study area [21] could be the potential reason for the inefficiency of LSIU smallholder farmers as compared to the SSIU and NU farmers. Introducing appropriate irrigation water prices could increase the economic efficiency of LSIU smallholder farmers while also mitigating some lost revenue [52,53]. Therefore, by introducing appropriate irrigation water prices and adopting best practices of efficient smallholder farmers and/or operating at optimal scales, the output of LSIU, SSIU and NU farmers could be increased, on average, by $79 \%, 40 \%$ and $53.5 \%$, respectively. In other words, due to their traditional farming practices such as poor agronomic practices, primitive postharvest handling mechanisms, traditional soil conservation measures, ineffective extension services, low education level of the household head and too cheap irrigation water prices in the study area, LSIU, SSIU and NU smallholder farmers lost, on average, about 143,781, 19,260 and 8615 Ethiopian Birr per year, respectively (see Table 5).

Table 6. TE scores and marginal effects of inefficiency determinants.

\begin{tabular}{|c|c|c|c|c|c|c|c|c|c|c|c|}
\hline \multicolumn{12}{|c|}{ TE Scores of Smallholder Farmers by Farm System Types } \\
\hline $\begin{array}{l}\text { Farmers } \\
\text { Type }\end{array}$ & \multicolumn{2}{|c|}{ Overall Farmers } & \multicolumn{2}{|c|}{ Large-Scale Irrigation Users } & \multicolumn{2}{|c|}{$\begin{array}{l}\text { Small-Scale } \\
\text { Irrigation Users }\end{array}$} & \multicolumn{2}{|c|}{ All Irrigation Users } & \multicolumn{3}{|c|}{ All Non-User Farmers } \\
\hline $\begin{array}{c}\text { TE } \\
\text { score } \\
\%\end{array}$ & 44.33 & $(0.21)$ & 21.05 & $(0.12)$ & 60.29 & $(0.18)$ & 42.56 & $(0.23)$ & & 46.47 & $(0.15)$ \\
\hline \multicolumn{12}{|c|}{ Marginal effect (ME) of TE determinates } \\
\hline \multicolumn{3}{|c|}{ TE determinates } & ME & S.D & \multicolumn{4}{|c|}{ TE determinates } & ME & \multicolumn{2}{|r|}{ S.D } \\
\hline \multicolumn{3}{|c|}{$\operatorname{lnSize}$} & 0.619 & $(0.14)$ & \multicolumn{4}{|c|}{ Irrigation Water availability } & -0.426 & & $(0.05)$ \\
\hline \multicolumn{3}{|c|}{ Education } & -0.013 & $(0.01)$ & \multicolumn{4}{|c|}{ Dependency Ratio } & -0.194 & & $(0.16)$ \\
\hline \multicolumn{3}{|c|}{ Plot soil quality } & -0.119 & $(0.06)$ & \multicolumn{4}{|c|}{ Crop type } & -0.439 & & $(0.09)$ \\
\hline \multirow{2}{*}{\multicolumn{3}{|c|}{$\begin{array}{c}\text { Improved Storage Facilities } \\
\text { Dry Facilities }\end{array}$}} & -0.162 & $(0.10)$ & \multicolumn{4}{|c|}{ Crop rotation } & 0.243 & & $(0.11)$ \\
\hline & & & 0.116 & $(0.02)$ & \multirow{2}{*}{\multicolumn{4}{|c|}{ Row planting }} & -0.133 & & $(0.09)$ \\
\hline \multicolumn{3}{|c|}{ Irrigation Options } & 0.622 & $(0.08)$ & & & & & & & \\
\hline
\end{tabular}

Note: standard deviations are reported in parenthesis. Marginal effects of inefficiency computed only for the statistically significant determinants of the technical efficiency (TE) in the stochastic frontier production function model. 
The marginal effects of statistically significant (in)efficiency determinants are also presented in Table 6. The negative (positive) coefficients of the variable imply that smallholder farmers with a larger value of that variable tend to have a higher (lower) level of TE. Family size of the household, crop dry facilities, crop rotation and irrigation options, for instance, have statistically significant positive coefficients, implying that the higher the value of these variables, the lower the TE of smallholder farmers (and the higher the technical inefficiency of smallholder farmers). According to Tenaye [43], the statistically significant negative effects of family size on the TE are explained by the dependence ratio in the household. Moreover, it is also explained by the fact that smallholder farmers in the study area produce crops, on average, on a one-half hectare of plot land, which is very small to accommodate the large number of laborers in the crop production process. The larger the family size, the bigger the number of the workforce (active family members of the household) and the smaller the dependency ratio. Thus, given a very small farm plot size, an increase in workforce for the crop production process results in low TE. For instance, in this paper, the effect of dependency ratio on the TE was found to be positive and statistically significant at $1 \%$ significance level, implying that the negative relationship between family size and TE emanates from the number of members of the household who actively participated in the crop production process. The statistically significant negative relationship between family size and TE is in line with the results obtained by others in the literature $[43,48]$.

In principle, the crop dry facilities and crop rotation are expected to have positive effects on the TE (negative effects on the technical inefficiency) of smallholder farmers by reducing postharvest loss and increasing the productivity of farm plots, respectively. However, in this study area, the crop drying facilities are very primitive and expose crops to being overrun by birds, rodents, rats and so on. This results in high postharvest loss outweighing the benefits, as it is very primitive, and results in lower TE. The negative effects of crop rotation on the TE, on the other hand, might result from the farmers adhering to the general principles of crop rotation without properly implementing its basic principles. The basic principle of crop rotation farming technique is to plant leguminous crops after the cereal crops and then leave the land undisturbed for at least one season. Poor extension service, limited crop production knowledge and skill coupled with very small farm plot sizes, however, make it much too difficult for the stallholder farmers to properly implement the crop rotation practices and benefit from these management practices. For instance, Sainju [54] studied the effect of crop rotations on yield and efficiency under traditional versus improved practices from 2006 to 2011 in the northern Great Plains, USA, and they found that the yield and efficiency are higher for the crop rotation under improved practices. The (in)efficiency determinant variable, irrigation option, has statistically significant negative effects on the TE of smallholder farmers in the study areas, implying that having access to large-scale irrigation water, for instance, is associated with a reduction in TE of about $62 \%$ (see Table 6 ). The Koga large-scale irrigation scheme was recently implemented, and thus the inexperience of farmers with this new agricultural technique coupled with poor extension service and too cheap irrigation water price explain the technical inefficiency of LSIU smallholder farmers. This result is in line with the results of the empirical literature [20].

Among the positive and statistically significant determinants of the TE of smallholder farmers, as they are dummy variables and will automatically have a higher ME because their ME is computed based on odds ratio, crop type achieved the highest value followed by irrigation water availability, dependency ratio, improved storage facilities, row planting and household head education. The ME value of -0.439 for crop type implies that a shift from harvesting staple crops to cash crops leads on average to a $44 \%$ increase in TE. This result is in line with the results of the empirical literature $[55,56]$. Although irrigation options negatively affected the TE (positively affected the technical inefficiency) of smallholder farmers, the availability of irrigation water was found to have a positive effect on the TE of smallholder farmers. Having access to water to irrigate the farm plot for one more cropping season results in an increase in the TE by about $16 \%$, indicating that farmers who have better access to water resources, be it either in the LSIU or SSIU, are technically more efficient. Similarly, a unit increase in the dependency ratio, plot soil quality and household head education are associated with an increase in TE of about $19 \%, 12 \%$ and $1 \%$, respectively. Although the magnitude is very small, education plays an imperative role in improving farmers' knowledge and skills of better crop production practices and mitigating the TE. Other studies report that irrigation water availability and education are the most influential factors affecting the TE of farmers in Pakistan [57]. Among the agronomic practices, row planting positively affects the TE of smallholder farmers in the study area. Practicing row planting is associated with an increase in TE of about $13 \%$. Indeed, row planting increases gas exchange, prevents excessive humidity, maximizes light exposure, minimizes excessive shading effect of other plants and thus favors more efficient photosynthesis and crop yield [58]. 
Moreover, unlike other agronomic practices such as mixed cropping and crop rotation, row planting requires relatively simple skill and knowledge, and thus it is more easily implemented by the farmers in the study area. Access to improved crop storage facilities also has a positive effect on the TE of smallholder farmers, implying that lack of improved crop storage facilities is associated with a reduction in TE of about $16 \%$. This may be attributed to the postharvest loss issue due to the use of traditional crop storage facilities, whereas access to improved storage facilities contributes to increased production and better quality of crops [59].

\section{Conclusions}

The degree to which traditional farming practices constrain agricultural productivity in Ethiopia, and the sources of (in)efficiency associated with the traditional farming practices, are not yet resolved. Using a technology-flexible stochastic frontier approach in which we considered both observed and unobserved heterogeneity, this study investigated the performance of smallholder farmers with different farm system types (LSIU, SSIU and NU farmers) in Ethiopia, focusing on the degree of technical (in)efficiency and its determinants. The result indicates that the average TE of smallholder farmers in the study areas was about $44 \%$ and varied across the farm system types. LSIU farmers were the most inefficient farmers with a TE score of $21 \%$ followed by NU $(46 \%)$ and SSIU $(60 \%)$. In other words, due to the traditional farming practices such as poor agronomic practices, primitive postharvest handling mechanisms, traditional soil conservation measures, ineffective extension services, low education level of the household head and too cheap irrigation water prices in the study area, LSIU, SSIU and NU smallholder farmers lost, on average, about 143,781 ETB/year, $19,260 \mathrm{ETB} /$ year and $8615 \mathrm{ETB} /$ year, respectively. This implies that there is a wider room for increasing crop production in the study areas through mitigating the technical (in)efficiency of smallholder farmers without additional investment in novel agricultural technologies.

Moreover, these findings suggest that modern postharvest handling technologies, soil conservation and water management measures, improved agronomic practices, farm-based education and an introduction of appropriate irrigation water prices are crucial to improve the TE of smallholder farmers in the study areas. Indeed, policy measures to facilitate the adoption of more efficient agronomic practices, improved postharvest handling technologies, soil conservation measures, modern extension services, farm-based education and training for smallholder farmers and irrigation water prices are expected to increase technical efficiencies. In addition, the results indicate that improving irrigation infrastructure can shift the frontier up and have a positive impact on smallholder farmers output. Thus, improving irrigation infrastructure (changing earthen canals into well-constructed cemented canals and reconstructing the poorly designed and broken cemented canals) in the study area is also important to bring development.

Author Contributions: In this paper, M.C.Z. designed the research, collected and analyzed the data and drafted the manuscript. S.V.P. supervised the whole work and contributed to reviewing the manuscript. M.M., D.B.T., Z.A.A., J.N., E.A.T. and A.S.M. contributed to reviewing the manuscript. All authors have read and agreed to the published version of the manuscript.

Funding: This research received no external funding.

Institutional Review Board Statement: Not applicable.

Informed Consent Statement: Not applicable.

Data Availability Statement: The data presented in this study are available on request from the corresponding author. The data are not publicly available due to restrictions.

Acknowledgments: The authors would like to thank Bahir Dar University, Institutional University Cooperation (BDU-IUC) VLIR_UOS project for providing us enough funds for the completion of this study. Special gratitude is given to Abrehet Kahsay for helping us to map this study area. The authors also gratefully acknowledge the Mecha and Fogera District Agricultural Office managers and kebele level officers for their support during the data collection.

Conflicts of Interest: The authors declare no conflict of interest. 
Appendix A

Table A1. Descriptive statistics.

\begin{tabular}{|c|c|c|c|c|c|}
\hline \multirow[b]{2}{*}{ Variables Name } & \multicolumn{5}{|c|}{ The Mean Value Variables Included in the SPFM } \\
\hline & LSIU (n = 254) & $\begin{array}{c}\text { SSIU } \\
(\mathrm{n}=308)\end{array}$ & $\begin{array}{l}\text { Users All } \\
(\mathrm{n}=562)\end{array}$ & $\begin{array}{c}N U \\
(n=464)\end{array}$ & $\begin{array}{c}\text { All } \\
(\mathrm{n}=1026)\end{array}$ \\
\hline $\begin{array}{c}\text { Output } \\
\text { Annual value of } \\
\text { crops harvest (Q) } \\
\text { Inputs }\end{array}$ & $\begin{array}{l}43,357.550 \\
(70,435.190)\end{array}$ & $\begin{array}{c}26,066.590 \\
(20,351.560)\end{array}$ & $\begin{array}{c}33,881.370 \\
(50,380.650)\end{array}$ & $7429.933(7207.774)$ & $21,918.93(39,826.697)$ \\
\hline Labor (A) & $3.874(1.745)$ & $\begin{array}{c}2.461 \\
(0.932)\end{array}$ & $\begin{array}{l}3.100 \\
(1.531)\end{array}$ & $\begin{array}{l}2.903 \\
(1.330)\end{array}$ & $\begin{array}{c}3.011 \\
(1.446)\end{array}$ \\
\hline Land (B) & $\begin{array}{c}0.445 \\
(0.226)\end{array}$ & $\begin{array}{c}0.288 \\
(0.176)\end{array}$ & $\begin{array}{c}0.359 \\
(0.214)\end{array}$ & $\begin{array}{l}0.367 \\
(0.198)\end{array}$ & $\begin{array}{c}0.362 \\
(0.207)\end{array}$ \\
\hline Capital (C) & $\begin{array}{c}9.299 \\
(3.123)\end{array}$ & $\begin{array}{l}10.594 \\
(3.833)\end{array}$ & $\begin{array}{l}10.009 \\
(3.585)\end{array}$ & $\begin{array}{l}2.756 \\
(1.162)\end{array}$ & $\begin{array}{c}6.729 \\
(4.548)\end{array}$ \\
\hline \multicolumn{6}{|l|}{$\begin{array}{c}\text { Farmers } \\
\text { Characteristics }\end{array}$} \\
\hline Size & $\begin{array}{l}7.366 \\
(2.032)\end{array}$ & $\begin{array}{l}6.640 \\
(2.102)\end{array}$ & $\begin{array}{l}6.968 \\
(2.101)\end{array}$ & $\begin{array}{l}6.692 \\
(2.182)\end{array}$ & $\begin{array}{l}6.843 \\
(2.141)\end{array}$ \\
\hline Education & $\begin{array}{l}2.539 \\
(2.750)\end{array}$ & $\begin{array}{c}2.672 \\
(3.035)\end{array}$ & $\begin{array}{c}2.612 \\
(2.906)\end{array}$ & $\begin{array}{l}2.129 \\
(2.810)\end{array}$ & $\begin{array}{c}2.394 \\
(2.873)\end{array}$ \\
\hline Gender & $\begin{array}{c}0.980 \\
(0.139)\end{array}$ & $\begin{array}{c}0.883 \\
(0.322)\end{array}$ & $\begin{array}{c}0.927 \\
(0.260)\end{array}$ & $\begin{array}{c}0.927 \\
(0.261)\end{array}$ & $\begin{array}{c}0.927 \\
(0.260)\end{array}$ \\
\hline Dependency ratio & $\begin{array}{l}1.185 \\
(0.957)\end{array}$ & $\begin{array}{l}1.943 \\
(1.202)\end{array}$ & $\begin{array}{c}1.601 \\
(1.160)\end{array}$ & $\begin{array}{l}1.609 \\
(1.157)\end{array}$ & $\begin{array}{l}1.604 \\
(1.158)\end{array}$ \\
\hline \multicolumn{6}{|l|}{$\begin{array}{l}\text { Postharvest } \\
\text { handling }\end{array}$} \\
\hline $\begin{array}{c}\text { Improved storage } \\
\text { facilities }\end{array}$ & $\begin{array}{c}0.394 \\
(0.490)\end{array}$ & $\begin{array}{c}0.675 \\
(0.469)\end{array}$ & $\begin{array}{c}0.548 \\
(0.498)\end{array}$ & $\begin{array}{c}0.017 \\
(0.130)\end{array}$ & $\begin{array}{c}0.308 \\
(0.462)\end{array}$ \\
\hline Crop dry facilities & $\begin{array}{c}0.394 \\
(0.490)\end{array}$ & $\begin{array}{c}0.932 \\
(0.252)\end{array}$ & $\begin{array}{c}0.689 \\
(0.463)\end{array}$ & $\begin{array}{c}0.183 \\
(0.387)\end{array}$ & $\begin{array}{c}0.460 \\
(0.499)\end{array}$ \\
\hline \multicolumn{6}{|l|}{$\begin{array}{l}\text { Access to } \\
\text { technologies }\end{array}$} \\
\hline Irrigation options & 2.000 & 1.000 & $\begin{array}{c}1.452 \\
(0.498)\end{array}$ & 0.000 & $\begin{array}{c}0.795 \\
(0.812)\end{array}$ \\
\hline $\begin{array}{l}\text { Irrigation water } \\
\text { availability }\end{array}$ & $\begin{array}{c}1.264 \\
(0.442)\end{array}$ & $\begin{array}{c}1.153 \\
(0.360)\end{array}$ & $\begin{array}{l}1.203 \\
(0.402)\end{array}$ & 0.000 & $\begin{array}{c}0.659 \\
(0.669)\end{array}$ \\
\hline Extension & $\begin{array}{l}1.596 \\
(1.323)\end{array}$ & $\begin{array}{c}0.792 \\
(0.406)\end{array}$ & $\begin{array}{l}1.156 \\
(1.020)\end{array}$ & $\begin{array}{c}0.645 \\
(0.743)\end{array}$ & $\begin{array}{c}0.925 \\
(0.940)\end{array}$ \\
\hline \multicolumn{6}{|l|}{$\begin{array}{c}\text { Plot level } \\
\text { characteristics }\end{array}$} \\
\hline Plot soil quality & $\begin{array}{c}3.260 \\
(0.900)\end{array}$ & $\begin{array}{c}4.961 \\
(0.210)\end{array}$ & $\begin{array}{c}4.192 \\
(1.052)\end{array}$ & $\begin{array}{c}4.024 \\
(1.065)\end{array}$ & $\begin{array}{c}4.116 \\
(1.061)\end{array}$ \\
\hline \multicolumn{6}{|l|}{ Agronomic practices } \\
\hline Crop type & $\begin{array}{c}0.047 \\
(0.213)\end{array}$ & $\begin{array}{c}0.588 \\
(0.493)\end{array}$ & $\begin{array}{c}0.343 \\
(0.475)\end{array}$ & $\begin{array}{c}0.009 \\
(0.093)\end{array}$ & $\begin{array}{c}0.192 \\
(0.394)\end{array}$ \\
\hline Crop rotation & $\begin{array}{c}0.980 \\
(0.139)\end{array}$ & $\begin{array}{c}0.987 \\
(0.113)\end{array}$ & $\begin{array}{c}0.984 \\
(0.126)\end{array}$ & $\begin{array}{c}0.567 \\
(0.496)\end{array}$ & $\begin{array}{c}0.795 \\
(0.404)\end{array}$ \\
\hline Crop conjunction & $\begin{array}{c}0.280 \\
(0.450)\end{array}$ & $\begin{array}{c}0.042 \\
(0.201)\end{array}$ & $\begin{array}{c}0.149 \\
(0.357)\end{array}$ & $\begin{array}{c}0.019 \\
(0.138)\end{array}$ & $\begin{array}{c}0.091 \\
(0.287)\end{array}$ \\
\hline Row planting & $\begin{array}{c}0.992 \\
(0.089)\end{array}$ & $\begin{array}{c}0.886 \\
(0.318)\end{array}$ & $\begin{array}{c}0.934 \\
(0.248)\end{array}$ & $\begin{array}{c}0.496 \\
(0.501)\end{array}$ & $\begin{array}{c}0.736 \\
(0.441)\end{array}$ \\
\hline
\end{tabular}

Note: standard deviations are reported in parenthesis. LSIU = large-scale irrigation user farmers; SSIU = small-scale irrigation user farmers; $\mathrm{NU}=$ irrigation non-user farmers.

Table A2. The constant return to scale (CRS) hypothesis test result.

\begin{tabular}{ccccccc}
\hline $\ln Q$ & Coef. & Std.Err. & $\mathbf{z}$ & $\mathbf{P}>\mathbf{z}$ & [95\%Conf. & Interval] \\
\hline & 3.056 & 0.521 & 5.860 & 0.000 & 2.034 & 4.078 \\
\hline
\end{tabular}




\section{References}

1. Central Intelligence Agency. The World Factbook—Irrigated Land. Available online: https://www.cia.gov/the-world-factbook/ (accessed on 22 February 2021).

2. The World Bank. Agricultural Irrigated Land (\% of Total Agricultural Land)—Ethiopia. Available online: https:// data.worldbank. org/indicator/AG.LND.IRIG.AG.ZS (accessed on 22 February 2021).

3. Worqlul, A.W.; Jeong, J.; Dile, Y.T.; Osorio, J.; Schmitter, P.; Gerik, T.; Srinivasan, R.; Clark, N. Assessing potential land suitable for surface irrigation using groundwater in Ethiopia. Appl. Geogr. 2017, 85, 1-13. [CrossRef]

4. Awulachew, S.B.; Ayana, M. Performance OF irrigation: An assessment at different scales in ethiopia. Exp. Agric. 2011, 47, 57-69. [CrossRef]

5. Seleshi, Y.; Camberlin, P. Recent changes in dry spell and extreme rainfall events in Ethiopia. Theor. Appl. Climatol. 2006, 83, 181-191. [CrossRef]

6. INDP. Ethiopia's Progress Towards Eradicating Poverty: Implementation of the Third United Nations Decade for the Eradication of Poverty (2018-2027); United Nations: New York, NY, USA, 2018.

7. TheGlobalEconomy.com. Ethiopia Economic Indicators. Available online: https:/ /www.theglobaleconomy.com (accessed on 24 February 2021).

8. Awulachew, S.B. Irrigation Potential in Ethiopia Constraints and Opportunities for Enhancing the System; IWMI: Addis Ababa, Ethiopia, 2010.

9. Taffesse, A.S.; Dorosh, P.; Gemessa, S.A. Crop production in Ethiopia: Regional patterns and trends. Food Agric. Ethiop. Prog. Policy Chall. 2013, 9780812208, 53-83.

10. Asefa, S. Analysis of Technical Efficiency of Crop Producing Smallholder Farmers in Tigray, Ethiopia. Munich Pers. RePEc Arch. (MPRA) 2011, 40461, 1-25.

11. Zewdie, M.C.; Van Passel, S.; Cools, J.; Tenessa, D.B.; Ayele, Z.A.; Tsegaye, E.A.; Minale, A.S.; Nyssen, J. Direct and indirect effect of irrigation water availability on crop revenue in northwest Ethiopia: A structural equation model. Agric. Water Manag. 2019, 220, 27-35. [CrossRef]

12. Zewdie, M.C.; Van Passel, S.; Moretti, M.; Annys, S.; Tenessa, D.B.; Ayele, Z.A.; Tsegaye, E.A.; Cools, J.; Minale, A.S.; Nyssen, J. Pathways how irrigation water affects crop revenue of smallholder farmers in northwest Ethiopia: A mixed approach. Agric. Water Manag. 2020, 233, 106101. [CrossRef]

13. Mango, N.; Makate, C.; Tamene, L.; Mponela, P.; Ndengu, G. Adoption of small-scale irrigation farming as a climate-smart agriculture practice and its influence on household income in the Chinyanja Triangle. Southern Africa. Land 2018, 7, 49. [CrossRef]

14. Gebrehiwot, K.G.; Daniel, M.; Woldu, T. The impact of micro-irrigation on households' welfare in the northern part of Ethiopia: An endogenous switching regression approach. Stud. Agric. Econ. 2017, 119, 160-167. [CrossRef]

15. Adela, F.A.; Aurbacher, J.; Abebe, G.K. Small-scale irrigation scheme governance-poverty nexus: Evidence from Ethiopia. Food Secur. 2019, 11, 897-913. [CrossRef]

16. Hagos, F.; Mulugeta, A.; Erkossa, T.; Langan, S.; Lefore, N.; Abebe, Y. Poverty Profiles and Nutritional Outcomes of Using Spate Irrigation in Ethiopia. Irrig. Drain. 2017, 66, 577-588. [CrossRef]

17. Yigzaw, N.; Mburu, J.; Ackello-Ogutu, C.; Whitney, C.; Luedeling, E. Stochastic impact evaluation of an irrigation development intervention in Northern Ethiopia. Sci. Total Environ. 2019, 685, 1209-1220. [CrossRef]

18. Triebs, T.P.; Saal, D.S.; Arocena, P.; Kumbhakar, S.C. Estimating economies of scale and scope with flexible technology. J. Product. Anal. 2016, 45, 173-186. [CrossRef]

19. Wang, H.J.; Schmidt, P. One-step and two-step estimation of the effects of exogenous variables on technical efficiency levels. J. Product. Anal. 2002, 18, 129-144. [CrossRef]

20. Annys, S. Impact of River Regulation on Downstream Socio-Hydrologic Systems in Ethiopia. Ph.D. Thesis, Ghent University, Gent, Belgium, 2020.

21. Taherdoost, H. Sampling Methods in Research Methodology; How to Choose a Sampling Technique for Research. Int. J. Adv. Res. Manag. 2016. [CrossRef]

22. Coelli, T.; Fleming, E. Diversification Economies and Specialisation Efficiencies in a Mixed Food and Coffee Smallholder Farming System in Papua New Guinea Tim Coelli and Euan Fleming University of Queensland and University of New England, Australia. Agric. Econ. 2004, 31, 229-239. [CrossRef]

23. Coelli, T. Estimators and Hypothesis Tests for a Stochastic Frontier Function: A Monte Carlo Analysis. J. Product. Anal. 1995, 6, 247-268. [CrossRef]

24. Kumbhakar, S.C.; Wang, H.-J.; Horncastle, A.P. A Practitioner's Guide to Stochastic Frontier Analysis Using Stata; Cambridge University Press: Cambridge, UK, 2015.

25. Aigner, D.; Lovell, C.A.K.; Schmidt, P. Formulation and estimation of stochastic frontier production function models. J. Econom. 1977, 6, 21-37. [CrossRef]

26. Akridge, J.T.; Hertel, T.W. Cooperative and Investor-Oriented Firm Efficiency: A Multiproduct Analysis. J. Agric. Coop. 1992, 7 , $1-14$.

27. Gezahegn, T.W.; van Passel, S.; Berhanu, T.; D'haese, M.; Maertens, M. Do bottom-up and independent agricultural cooperatives really perform better? Insights from a technical efficiency analysis in Ethiopia. Agrekon 2020, 59, 93-109. [CrossRef]

28. Stevenson, R.E. Likelihood functions for generalized stochastic frontier estimation. J. Econom. 1980, 13, 57-66. [CrossRef] 
29. Gujarati, D.N. Basic Econometrics, 4th ed.; McGraw Hill: New York, NY, USA, 2003.

30. Holgersson, H.E.T.; Nordström, L.; Öner, Ö. Dummy variables vs. category-wise models. J. Appl. Stat. 2014, 41, 233-241. [CrossRef]

31. Schepers, J. On regression modelling with dummy variables versus separate regressions per group: Comment on Holgersson et al. J. Appl. Stat. 2016, 43, 674-681. [CrossRef]

32. Kumbhakar, S.C.; Lovell, C.A.K. Stochastic Frontier Analysis; Cambridge University Press: Cambridge, UK, 2000.

33. Schmidt, P.; Jondrow, J.; Knox, C.A.; Schmidt, P. On The Estimation of Technical Inefficiency in The Stochastic Frontier Production Function Model. J. Econ. 1982, 19, 233-238.

34. Battese, G.T.C. A Model for Technical Inefficiency Effects in a Stochastic Frontier Production Function for Panel Data. J. Econom. 1995, 20, 325-332. [CrossRef]

35. Caudill, S.B.; Ford, J.M. Biases in frontier estimation due to heteroscedasticity. Econ. Lett. 1993, 41, 17-20. [CrossRef]

36. Caudill, S.B.; Ford, J.M.; Gropper, D.M.; Caudill, S.B.; Ford, J.M. Frontier Estimation and Firm-Specific Inefficiency Measures in the Presence of Heteroscedasticity. J. Bus. Econ. Stat. 1995, 13, 105-111.

37. Hadri, K. Estimation of a doubly heteroscedastic stochastic frontier cost function. J. Bus. Econ. Stat. 1999, 17, 359-363.

38. Wang, H.J. Heteroscedasticity and non-monotonic efficiency effects of a stochastic frontier model. J. Product. Anal. 2002, 18, 241-253. [CrossRef]

39. Kumbhakar, S.C.; Wang, H.-J. Estimation of Technical Inefficiency in Production Frontier Models Using Cross-Sectional Data; Cambridge University Press: Cambridge, UK, 2015.

40. Jan van Garderen, K.; Shah, C. Exact interpretation of dummy variables in semilogarithmic equations. Econom. J. 2002, 5, 149-159. [CrossRef]

41. Abdul-Rahaman, A.; Abdulai, A. Do farmer groups impact on farm yield and efficiency of smallholder farmers? Evidence from rice farmers in northern Ghana. Food Policy 2018, 81, 95-105. [CrossRef]

42. Bravo-Ureta, B.E.; Higgins, D.; Arslan, A. Irrigation infrastructure and farm productivity in the Philippines: A stochastic Meta-Frontier analysis. World Dev. 2020, 135, 105073. [CrossRef]

43. Tenaye, A. Technical efficiency of smallholder agriculture in developing countries: The case of Ethiopia. Economies 2020, 8, 34. [CrossRef]

44. Croppenstedt, A.; Demeke, M. An empirical study of cereal crop production and technical efficiency of private farmers in Ethiopia: A mixed fixed-random coefficients approach. Appl. Econ. 1997, 29, 1217-1226. [CrossRef]

45. Turner, N.C. Agronomic options for improving rainfall-use efficiency of crops in dryland farming systems. J. Exp. Bot. 2004, 55, 2413-2425. [CrossRef] [PubMed]

46. Geffersa, A.G.; Agbola, F.W.; Mahmood, A. Technology adoption and technical efficiency in maize production in rural Ethiopia. Afr. J. Agric. Resour. Econ. 2019, 14, 184-201.

47. Seyoum, E.T.; Battese, G.E.; Fleming, E.M. Technical efficiency and productivity of maize producers in eastern Ethiopia: A study of farmers within and outside the Sasakawa-Global 2000 project. Agric. Econ. 1998, 19, 341-348.

48. Abate, T.M.; Dessie, A.B.; Mekie, T.M. Technical efficiency of smallholder farmers in red pepper production in North Gondar zone Amhara regional state, Ethiopia. J. Econ. Struct. 2019, 8, 1. [CrossRef]

49. Ngango, J.; Kim, S.G. Assessment of technical efficiency and its potential determinants among small-scale coffee farmers in rwanda. Agriculture 2019, 9, 161. [CrossRef]

50. Bogale, T.; Bogale, A. Technical efficiency of resource use in the production of irrigated potato: A study of farmers using modern and traditional irrigation schemes in Awi Zone, Ethiopia. J. Agric. Rural Dev. Trop. Subtrop. 2005, 106, 59-70.

51. Adams, A.; Balana, B.; Lefore, N. Efficiency of Small-scale Irrigation Farmers in Northern Ghana: A Data Envelopment Analysis Approach. Margin J. Appl. Econ. Res. 2020, 14, 332-352. [CrossRef]

52. Varela-Ortega, C.; Sumpsi, J.M.; Garrido, A.; Blanco, M.; Iglesias, E. Water pricing policies, public decision making and farmers' response: Implications for water policy. Agric. Econ. 1998, 19, 193-202. [CrossRef]

53. Zeff, H.; Characklis, G.W.; Thurman, W. How Do Price Surcharges Impact Water Utility Financial Incentives to Pursue Alternative Supplies during Drought? J. Water Resour. Plan. Manag. 2020, 146, 1-9. [CrossRef]

54. Sainju, U.M.; Lenssen, A.W.; Allen, B.L.; Jabro, J.D.; Stevens, W.B. Stacked crop rotations and cultural practices for canola and flax yield and quality. Agron. J. 2020, 112, 2020-2032. [CrossRef]

55. Sell, M.; Bäckman, S.; TettehAnang, B.; Niemi, J.K. The unequal efficiency gap: Key factors influencing women farmer's efficiency in Uganda. Cogent Food Agric. 2018, 4, 1-18. [CrossRef]

56. Ogundari, K.; Brümmer, B. Technical efficiency of Nigerian agriculture: A meta-regression analysis. Outlook Agric. 2011, 40, 171-180. [CrossRef]

57. Watto, M.; Mugera, A. Wheat farming system performance and irrigation efficiency in Pakistan: A bootstrapped metafrontier approach. Int. Trans. Oper. Res. 2019, 26, 686-706. [CrossRef]

58. Pajčin, Đ.; Vuckovic, S.; Popovic, V.; Simic, A.; Popovic, S.; Jovanovic-Radovanov, K.; Simic, D.; Vujosevic, A. Effects of row spacing and plant growth regulation on alfalfa seed yield (Medicago sativa L.). Pak. J. Bot. 2020, 52, 1757-1762. [CrossRef]

59. Senapati, A.K. Evaluation of risk preferences and coping strategies to manage with various agricultural risks: Evidence from India. Heliyon 2020, 6, e03503. [CrossRef] 